ZBIGNIEW ROMANIUK (Brańsk)

\title{
LUDWIK ZAMENHOF - NIEZNANE SZCZEGÓ£Y BIAŁOSTOCKIEGO ŻYCIORYSU
}

Zdawać by się mogło, że postać Ludwika Zamenhofa, który zdecydowanie zdystansował wiele znamienitych postaci w szeroko rozpropagowanym przez lokalne media plebiscycie Biatostoczanie $X X w$., jest bardzo dobrze znana. Podstawowe fakty $z$ jego życiorysu nie stanowią już zagadki, szczególnie jeśli chodzi o jego białostocki rozdział. Wbrew pozorom, o Zamenhofach i ich pobycie w Białymstoku wiadomo bardzo mało. Informacje powielane w różnych publikacjach niestety ugruntowały błędny życiorys Zamenhofa, oparty bardziej na domysłach niż faktach. Głównym powodem takiego stanu był brak badań historycznych nad biografią Ludwika. Dotychczas o Zamenhofie pisali zazwyczaj esperantyści rozmiłowani w swym mistrzu, zamykając się w kręgu powielanych i coraz to bardziej upiększanych "faktów"1.

1 Ważniejsze publikacje: Leteroj de L., L. Zamenhof, t. I, Paryż 1948; J. Muszyński, Zarys historii języków międzynarodowych a język esperanto, Łódź 1948; E. Privat, Życie dra Zamenhofa twórcy międzynarodowego języka esperanto, tłum. J. Pióro, Poznań 1957 (pierwsze wydanie za granicą w 1920 r.); M. Ziółkowska, Doktor Esperanto, Warszawa 1959; M. Boulton, Creator of Esperanto, 1959; I. Lapennae, Podstawowe fakty o języku międzynarodowym (esperanto), Wrocław 1965; R. Kraśko, Ludwik Zamenhof-twórca esperanto. Studia i materiały do dziejów miasta Biategostoku, 1972, t. 3, s. 121-147; ostatnio wiele miejsca Zamenhofowi poświęcono w numerze 19 (1999 r.) białostockiego magazynu historycznego "Gryfita”. Najnowsza biografia: Z. Banet-Fornalowa, La familio Zamenhof. Originala biografia studo, Postpar, G. Silfer, La Chaux-de-Fonds: Kooperativo de Literatura Foiro, 2001 (recenzja: H. Brown, Ne nur pri Ludoviko, „La Ondo de Esperanto" 2001, nr 12). Esperantystami nie sa, ale o Zamenhofie pisali też: T. Wiśniewski, Ludwik Zamenhof, Białystok 1987; krótki biogram Zamenhofa zawiera książka: Białostoczanie XX wieku. Wielki plebiscyt Gazety Wyborczej, Radia Biatystok i Telewizji Biatystok, Białystok 2000; też J. Trynkowski, Gimnazjum. Z dziejów Gimnazjum Białostockiego (1777) 1802-1915, Białystok 2002, s. 311-313. 
Badając zagadnienia związane $\mathrm{z}$ białostockimi Żydami, natknąłem się na powszechnie dostępne od wielu lat akta, które znacząco zmieniają i uzupełniają białostocki życiorys Ludwika i jego rodziny. Przejrzenie zasobów archiwalnych w Grodnie i Białymstoku przyniosło w tym względzie wręcz rewelacyjne ustalenia.

W Tykocinie uwagę przykuwa tablica z brązu przytwierdzona w $1999 \mathrm{r}$. do kamienicy naprzeciwko słynnej synagogi. Dwujęzyczny polsko-esperancki napis głosi, że ufundowano ją Markowi Zamenhofowi, ojcu słynnego Ludwika, który miał się urodzić 27 stycznia 1837 r. w Tykocinie. Bardzo dobrze zachowane tykocińskie akta żydowskich urodzeń z lat 1826-1844 niestety nie zawierają wpisów, które mogłyby to potwierdzić. Przy okazji ustaliłem, że Zamenhofowie przybyli do Tykocina dopiero około połowy XIX w., skąd po kilku bądź kilkunastu latach przeprowadzili się do Białegostoku².

W Archiwum Państwowym w Białymstoku znajduje się niemal komplet żydowskich ksiąg stanu cywilnego $\mathrm{z}$ drugiej połowy XIX w. Tutaj jest też akt urodzenia-obrzezania Ludwika Zamenhofa. Pomimo że fakt ten był znany od szeregu lat, żaden $z$ historyków nie analizował jego treści. Po raz pierwszy zacytuję pełną treść tego dokumentu, w tłumaczeniu na język polski (oryginał sporządzono w języku rosyjskim i hebrajskim):

Urodzenie płci męskiej, akt nr 47 z 1859 r. „Obrzezania dokonali Lejb Kon i Wolf Suraski. Urodzenie według kalendarza chrześcijańskiego 3, a obrzezanie 10 grudnia; według kalendarza żydowskiego urodzenie 19, a obrzezanie 26 dnia miesiąca kislew [5620 r.] w Białymstoku. Dane o rodzicach: Mordka Fejwelowicz Zamenow[!], Liba Szolemowna Sofer. Imię narodzonego dziecka Lejzer" ${ }^{3}$.

Polscy autorzy poszli przede wszystkim śladem powieści dokumentalnej Marii Ziółkowskiej o Doktorze Esperanto, a opisuje ona życie Ludwika w sposób dość swobodny, nie zawsze zgodny z prawdą. Stwierdzenia tej autorki weszły już niestety do kanonu podstawowej wiedzy o Ludwiku i trudno będzie to zmienić.

2 Archiwum Państwowe w Białymstoku (APB), Akta Stanu Cywilnego Okręgu Bóżniczego w Białymstoku (OB Białystok), sygn. 22, akt 25/ż/1862 - Fejgla, sygn. 42, akt $74 / \dot{z} / 1864$ - Gitla, dzieci Mordche Zamenhofa; sygn. 39, akt 82/m/1863 - Fajvel vel Fabian, sygn. 42, akt 234/m/1864 - Jankiel, dzieci Josla Wolfa Zamenhofa. W tych przypadkach przy rodzicach podano, że byli z miasta Tykocin. Chociaż faktycznie co najmniej od 1859 r. Mark z rodziną mieszkał już w Białymstoku, to do ksiąg miejskich i gminy żydowskiej w Białymstoku zapisano ich między 1864 a 1866 r., podobnie jak rodzinę jego brata Josla Wolfa. żeńskich.

Przy numerze aktu litera „m” oznacza numerację urodzeń męskich, a litera „ $\dot{z}^{\prime}$

3 APB, OB Białystok, sygn. 22, k. 22v-23, akt urodzenia nr 47/m/1859. 
Tyle mówi typowy akt urodzenia, który wymaga jednak dodatkowych objaśnień. Obrzezania nowo narodzonego dokonano ósmego dnia życia, co oznacza, że dziecko przyszło na świat zdrowe. Przyzwyczajono nas, że Zamenhof to Ludwik, a jego ojciec to Marek, matka zaś zwać się miała Rozalia. Skąd zatem te rozbieżności. W akcie urodzenia mamy do czynienia $z$ właściwą formą imion żydowskich.

Bliższa analiza akt pozwoliła na ustalenie, że Mordka (Mordche) Zamenhof zmienił imię na Marek oraz imię ojca Fajwla na Fabiana, co władze dokumentem z 20 kwietnia 1871 r. poleciły wpisać na marginesie wcześniejszego aktu urodzenia jego córki Fejgli z 1862 r. ${ }^{4}$ Wytarto wówczas w tym dokumencie poprzednio wpisane imiona „Mordka Fajwelowicz” i w to miejsce wpisano "Mark Fabianowicz". Pojawiająca się w tym czasie tendencja do zmiany tradycyjnych imion na brzmiące chrześcijańsko dotyczyła jeszcze niewielkiej części Żydów, którzy stopniowo odchodzili od ortodoksji. Z odpowiednim wykształceniem i chrześcijańsko brzmiącym imieniem było łatwiej o karierę urzędniczą. W przypadku Zamenhofa może miało to związek z czasowym, krótkim nauczaniem w białostockim gimnazjum, co nie jest jednak pewne. W przyszłych publikacjach ojca Ludwika należy określać więc jako Mordche vel Mark (Marek). Niekiedy w opracowaniach podaje się też brzmienie Markus, ale tej formy nie znalazłem w żadnym dokumencie archiwalnym, stąd uważam ją za mniej właściwą, pomimo jednoznaczności tych określeń.

Ponadto ciekawostkę stanowi fakt, że Mordche vel Mark Zamenhof wiosną 1862 r. jako swój wykonywany zawód podał - „buchalter” (księgowy). Pierwsza wzmianka o nim jako nauczycielu pojawia się w 1866 r., chociaż nie można wykluczyć, że był nim już wcześniej. Z pośrednich danych wynika, że Zamenhofom wiodło się nie najlepiej ${ }^{5}$.

Matka Ludwika w dokumentach $\mathrm{z}$ lat 1862-1871 konsekwentnie wymieniana jest jako Liba lub Liba Rochla. Podczas pobytu w Białymstoku

4 APB, OB Białystok, sygn. 35, akt 25/ż/1862, k. 22v - na marginesie aktu urodzenia odnotowano podstawę zmiany (sprostowania) imion z Mordka Fajwelowicza na Marka Fabianowicza: „Isprawleno po predpisaniu Dumy ot 8 aprela 1871 za nr 1343”.

5 A. Dylewski (Śladami Żydów polskich, 2002, s. 98 - przewodnik Pascala) przytaczając kilkuzdaniowy życiorys Ludwika bezpodstawnie twierdzi, że wychowywał się on „w zamożnej rodzinie nauczyciela języków obcych i jednego z fundatorów Synagogi Chóralnej" oraz że Zamenhof był cenionym okulistą. Synagogę Chóralną wzniesiono w 1834, a Marek przyszedł na świat w 1837 r., co wyklucza tę tezę. Zamenhof znacznie później mógł przynależeć do tej synagogi i jak wszyscy łożyć na jej utrzymanie i remonty. Ludwik nigdy nie był cenionym okulistą, a raczej przeciętnym. 


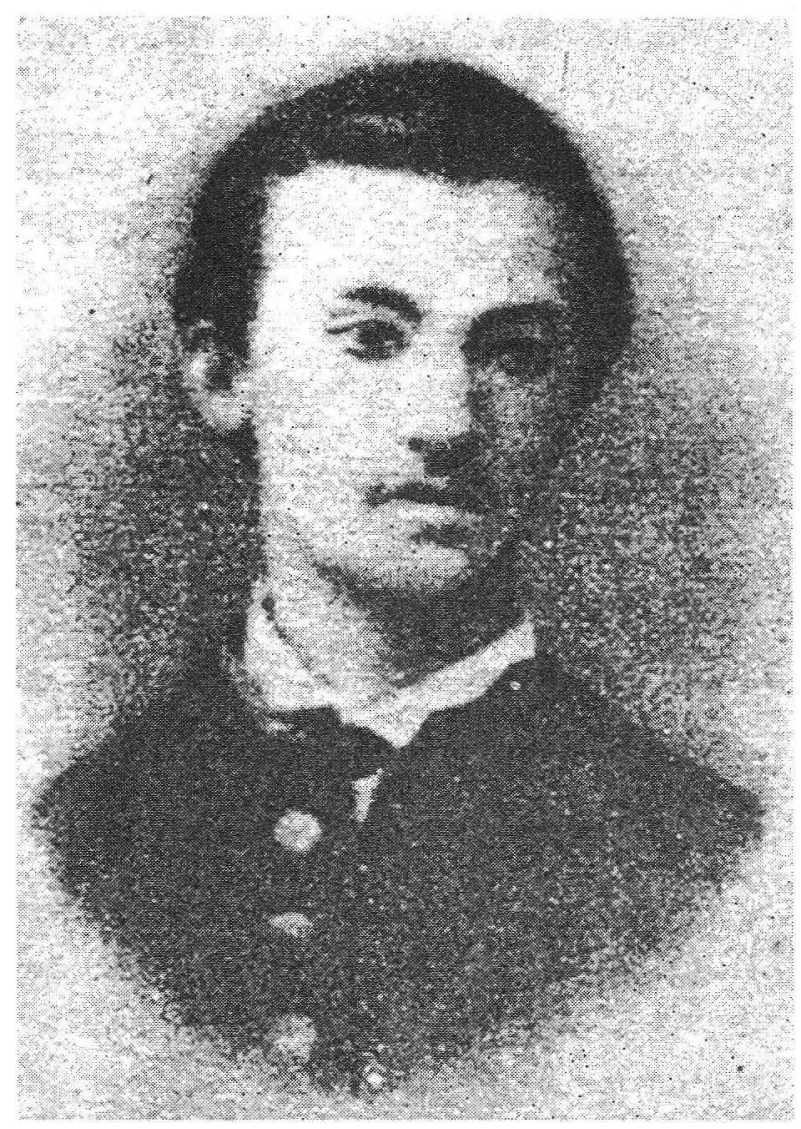

\section{Ludwik Zamenhof jako student}

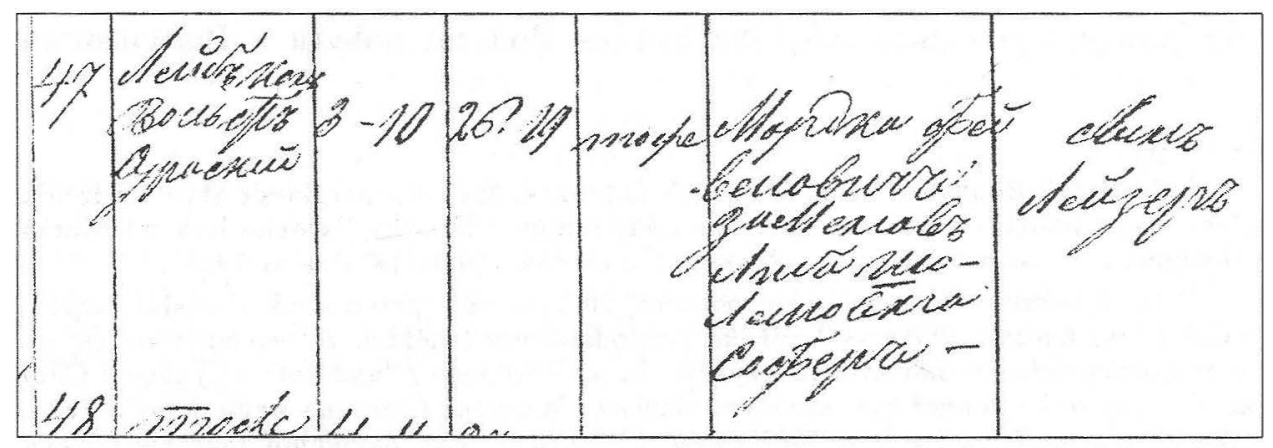

Akt urodzenia-obrzezania L. Zamenhofa, 1859 r. 
w sprawach urzędowych nie używała więc imienia Rozalia, które urobiono znacznie później, być może od Rochli. Właściwe imiona do obecnej chwili pozostawały nieznane. Nie stwierdziłem w Białymstoku ani jednego zapisu archiwalnego, w którym matkę Ludwika nazywano by Rozalią. Faktycznie była to Liba Rochla (Rachela).

Nieznane dotąd było biografom również imię dziadka Ludwika Zamenhofa, a był nim Fajwel vel Fabian. To on przybył do Tykocina ze swymi synami. W niektórych publikacjach żydowskich określano go jako Tobiasza, co nie odpowiada prawdzie. Wiadomo, że i on był nauczycielem, ponoć znacznie lepszym od Marka ${ }^{6}$. Podobnie nieznane pozostawało imię ojca żony Marka, Liby Rochli z domu Sofer, który nazywał się Szolem. Akt urodzenia dostarczył więc wielu nieznanych szczegółów o najbliższej rodzinie Ludwika.

Mordche Zamenhof w 1859 r. nie był chyba jeszcze osobą zbyt znaną w Białymstoku, skoro jego nazwisko zapisano błędnie w zruszczonej formie - Zamenow. Oficjalnie podaje się, że Ludwik Zamenhof urodził się 15 grudnia, a akt urodzenia wymienia 3 grudnia. Ta rozbieżność wynika ze stosowanego wówczas i narzuconego na naszych terenach urzędowego kalendarza juliańskiego. Według kalendarza gregoriańskiego Ludwik urodził się więc 15 grudnia, we czwartek. Według kalendarza żydowskiego - mierzonego od rzekomego stworzenia świata - było to 19 kislew 5620 r. Dwa dni później, w sobotę, zgodnie $\mathrm{z}$ żydowską tradycją ojciec musiał zorganizować przy jęcie dla mężczyzn zwane szalom zachar. W trakcie obrzezania, którego dokonano 22 grudnia (piątek), mohelem i sandakiem była para mężczyzn, którzy w Białymstoku zajmowali się tym niejako etatowo.

Sam Ludwik winien być zwany Lejzerem-Lazarem-Ludwikiem, gdyż imion w tych formach używał w trakcie swego życia. Oczywiście to ostatnie obrał sobie sam, bo z takim łatwiej było obcować pośród i z chrześcijanami. Imię Ludwik jest późniejszym fonetycznym powiązaniem Lejzera vel Lazara, w spolszczonej formie Łazarza. W trakcie pobytu w Białymstoku był to jeszcze Lejzer (Lazar), a nie Ludwik Zamenhof.

Zadziwiające jest jak mało faktów genealogicznych ustalili biografowie o rodzinie Zamenhofów. Okazu je się, że Fajwel vel Fabian Zamenhof (dziadek Ludwika) oprócz Mordche miał też drugiego, chyba młodszego syna - Josla Wolfa. Tenże $\mathrm{z}$ zawodu był drobnym handlarzem i mieszkał w Tykocinie. Około 1862 r. poślubił Sorę Ickownę, z którą już co najmniej od następnego roku mieszkał w Białymstoku. Mieli kilkoro dzieci: jedno po dziadku nosiło

6 Evrejskaja Enciklopedîja, S.-Peterburg, b.r.w., (dalej jako EE), t. VII, kol. 665. 
imię - Fajwel vel Fabian (ur. 3 VI 1863), Frejda zwana też Fryderyką (1868, zmarła w czerwcu 1870), ponadto był Jankiel (2 XII 1864), a z pewnością również Rebeka (1867) i Salomon (1870) ${ }^{7}$.

W publikacjach biograficznych pośród rodzeństwa Lejzera-Ludwika wymienia się urodzonych w Białymstoku: Sarę - 1860 r., Fanię - 1862 r., Augustę - 1864 r., Feliksa - 1868 r. i Henryka - 1871 r., a w Warszawie Idę, Leona - 1876 r. i Aleksandra - 1877 r. Porównajmy te dane z dokumentami stanu cywilnego przechowywanymi w Białymstoku: Fejgla vel Fagel urodzona 12 IV 1862 r. (to zapewne wspomniana Fania lub Feliksa), Gitla - 24 VIII 1864 r. (zapewne tożsama ze wspomnianą Augustą), Sora Dwora - 25 XI 1866 r. (to być może Sara, której urodzenie błędnie datowano na 1860 r.), Fabian (1868), Hersz (zm. 24 VII 1870 r., mając osiem tygodni), Grzegorz ur. 6 X 1871 r. (przez biografów niesłusznie nazywany Henrykiem). Jak widać odnalezione dokumenty zmieniają także nasze pojęcie o najbliższej rodzinie Ludwika. Dalsze poszukiwania pozwolą być może na odnalezienie aktu małżeństwa Mordka i Liby Rochli Zamenhofów, który dostarczyć może nowych szczegółów, podobnie jak akty zgonów członków rodziny8.

Kilka nieznanych faktów z życia Zamenhofów ustaliłem również na podstawie akt Państwowego Archiwum Historii Białorusi w Grodnie. Do Marka, a może jednak do jego ojca Fajwla, odnosi się wzmianka w rosyjskich dokumentach śledczych o nauczycielu Zamenhofie z Białegostoku, który często pisał różne donosy do władz carskich. Jeden $z$ tych donosów $w$ formie anonimu, dotyczył przybyłego z Warszawy do Białegostoku żydowskiego nauczyciela Bernarda Wildenbauma, obwinionego latem 1862 r. o noszenie polskiej odzieży narodowej. Policja w dochodzeniu podejrzewała, że ten anonim był sprawką Zamenhofa, gdyż prowadził on konkurencyjną szkołę dla dziewcząt ${ }^{9}$.

7 APB, OB Białystok, sygn. 39, akt 82/m/1863 - Fajwel vel Fabian; sygn. 42, akt 234/m/1864 - Jankiel; sygn. 27 - Skorowidz urodzeń z lat 1860-1883 (bez 1872 i 1880). Dokument ten częściowo uzupełnia zaginione księgi urodzeń i wymienia ponadto inne dzieci Zamenhofów: Rebeka (akt 13/1867), Salomon (akt 176/1870). W artykule daty urodzenia podałem po przeliczeniu, wg kalendarza gregoriańskiego. Ibidem, sygn. 66, księga zgonów z 1870 r., akt nr 86/ż/1870 - Frejda c. Josla zmarła w wieku dwóch lat na zapalenie płuc.

8 Odszukanie aktu małżeństwa Zamenhofów może nastręczyć problemów, gdyż nie odnalazłem go w aktach lat 1858-59 ani w Tykocinie, ani w Białymstoku. APB, OB Białystok, sygn. 27 - Fabian (akt 274/1868); sygn. 66, akt nr 110/m/1870 - 25 miesiąca tamuz z ogólnego osłabienia zmarło dziecko Hersz Moredkowicz[!] Zamenhof.

9 Państwowe Archiwum Historii Białorusi w Grodnie, sygn. 1/34/94, sprawę prowadzono od 14 VIII do 9 XII 1862 r.; Z. Romaniuk, Żydzi Białostoccy do 1915 r. Studia i materiały do dziejów miasta Białegostoku, Białystok 2001, s. 167-168. 
Zamenhof rzeczywiście posiadał w Białymstoku szkołę dla żydowskich dziewcząt. W 1866 r. uczęszczały do niej 63 uczennice. W konkurencyjnej szkole Kagana uczyły się 83 dziewczęta ${ }^{10}$. Marek początkowo zarobkował jako nauczyciel domowy u Zabłudowskich, najbogatszej żydowskiej rodziny w Białymstoku, a potem wspólnie $\mathrm{z}$ innymi młodymi nauczycielami otworzył szkołę „Tora ba dereh Erec" ("Tora drogą do Erec" - czyli do Izraela)11, która prawdopodobnie jest tożsama ze wspomnianą szkołą dla dziewcząt. Marek Zamenhof był nauczycielem języka niemieckiego i francuskiego. Jego ojciec Fajvel-Fabian, też językoznawca, uchodził za pioniera oświaty i kultury pośród białostockich Żydów ${ }^{12}$.

Biografowie podają też tajemniczą informację, jakoby Marek Zamenhof był nauczycielem w miejscowym białostockim gimnazjum (szkole realnej). Nie udało się potwierdzić tej informacji w źródłach i należy traktować ją bardzo ostrożnie. O ile jednak nauczał w tym gimnazjum, było to możliwe po powstaniu styczniowym. Ewentualne zatrudnienie Zamenhofa mogło być związane z czystką, jaka nastąpiła w szkolnictwie po 1863 r. Zwolniono wówczas wielu nauczycieli pochodzenia polskiego. W spisie pedagogów szkoły realnej w Białymstoku z 1870/71 r. nie ma Zamenhofa ${ }^{13}$.

Powszechnie przyjmuje się, że rodzina Zamenhofów w 1873 r. opuściła Białystok i przeniosła się do Warszawy. Marek dostąpił wówczas niewątpliwego zaszczytu wykładania języka niemieckiego w instytucie weterynarii i w szkole realnej, będąc jednym z trzech[!] Żydów dopuszczonych w tym czasie do pracy w warszawskich szkołach państwowych ${ }^{14}$. Ponadto miał on uzyskać tytuł „tajnego radcy" ${ }^{15}$. Co zatem spowodowało, że prowincjonalny nauczyciel z powiatowego Białegostoku nagle zyskał taką posadę i to $z$ tytułem o pewnej randze? Czym zaskarbił sobie zaufanie władz? Jaki był powód wyjazdu Zamenhofów do Warszawy? Otwartym pozostaja nie tylko te pytania.

10 Pamiatnaja knižka grodnenskoj guberni na 1866 god, Grodno 1866, s. 48-49. O żydowskim szkolnictwie w tym czasie w Białymstoku patrz: Z. Romaniuk, op. cit., s. $162-163$.

11 Z. Wajnsztejn, Największym Białegostoku, „Reflektor”, nr 29, 29 VIII 1931, s. 3. Jest to przedruk artykułu o drze Ludwiku Zamenhofie z "Polskiej Wolności”, nr 33 z 1931 r. Autor w białostockim życiorysie podaje częściowo błędne informacje.

12 EE, t. VII, kol. 665. Rodzina Marka, zapewne więc Fajwel-Fabian miał przybyć do Tykocina przez Grodno z Kurlandii. Z. Wajnsztejn, op. cit.

13 Pamiatnaja knižka grodnenskoj guberni na 1871 god, Grodna 1871, s. 57-58.

$14 E E$, t. VII, kol. 666.

15 Z. Wajnsztejn, op. cit. 
Inna odnaleziona jednostka archiwalna pozwala na istotną zmianę dotychczas poznanego życiorysu Ludwika, który faktycznie pozostał w Białymstoku jeszcze przez około dwa lata od wy jazdu ojca do Warszawy. Między bajki należy więc włożyć twierdzenia o ówczesnym pobycie młodego Zamenhofa w Warszawie, gdzie w 1873 r. miał pilnie przygotowywać się do egzaminów. Co zatem Ludwik robił w Białymstoku?

Biografowie podają, że od 1869 r. był on uczniem białostockiego gimnazjum (szkoły realnej). Niestety w znanych dokumentach nie ma o tym najmniejszej wzmianki. Natomiast z akt odnalezionych w Grodnie wiadomo, że dopiero jesienią 1872 r., po pozytywnie zdanym egzaminie, przyjęto go na dwuletni kurs białostockiego gimnazjum realnego. Pod nadzorem ojca uczył się do wiosny roku następnego, a potem, gdy rodzina wyjechała do Warszawy, pozostał w Białymstoku by dokończyć edukację. Nastolatek bez opieki najbliższej rodziny żył w Białymstoku własnymi, niekoniecznie szkolnymi sprawami. Niestety oblał pierwszy rok, głównie ze względu na naganne zachowanie. Repeta od początku mu nie szła i w końcu po niespełna dwóch miesiącach porzucił powtarzaną pierwszą klasę. Dyrektor Białostockiej Dyrekcji Szkół wyraził o Ludwiku opinię: „[...] nie tylko ostatecznie przestał się uczyć, ale ku zgorszeniu uczniów uciekał z klasy i w czasie lekcji włóczył się po mieście [...]". To dlatego decyzją rady pedagogicznej w końcu października 1874 r. usunięto go ze szkoły. W księdze postępów nauki, czyli dzienniku lekcyjnym, przy nazwisku Zamenhof wpisano „[...] postępy ze wszystkich przedmiotów słabe, sprawowanie niezadowalające" 16. Postać Ludwika dołączyć więc można do grona wybitnych ludzi, którzy w szkole nie zawsze radzili sobie najlepiej.

Wiek dorastania, młodzieńczego buntu, konflikty z ojcem i brak zrozumienia w rodzinie doprowadziły Ludwika do próby całkowitego zerwania $\mathrm{z}$ bliskimi, a nawet $\mathrm{z}$ religią przodków.

Wiosną 1875 r., zapewne gdy szkolnych porażek nie dało się już dłużej ukrywać przed rodziną, młody Zamenhof podjął desperacką decyzję ucieczki do Grodna, gdzie uczynił coś zadziwiającego - w połowie kwietnia napisał podanie do władz rosyjskich o zmianę wyznania $\mathbf{z}$ mojżeszowego na prawosławne. W dokumencie tym skłamał, że kończy szkołę w Białymstoku i dalej chce kontynuować naukę, ale ojciec odmawia finansowania. Ponadto Marek miał zmuszać go do wstąpienia na jakąkolwiek służbę państwową i to w tym celu miał on przybyć do Grodna.

16 Państwowe Archiwum Historii Białorusi w Grodnie, sygn. 1/7/1826, k. 3-4. Opinia dyrektora Białostockiej Dyrekcji Szkół o Lazarze Zamenhofie z 21 IV 1875 r. 
Ludwik w realizacji swego planu widział zasadniczą przeszkodę - wyznanie mojżeszowe. Stwierdzał: „[...] Żydom w ogóle nigdzie nie ma żadnej szansy w państwowej służbie [...]”. Dalej przekonywał: „[...] z czystego serca szczerze pragnę być prawdziwym prawosławnym człowiekiem i wiernym sługą swego monarchy i rosyjskiej ojczyzny [...]" oraz najpokorniej prosił, a nawet błagał ze łzami, aby carski urzędnik poczynił stosowne kroki w jego sprawie. Zastrzegł jednak, aby jego chrzest utrzymać w tajemnicy i do tego czasu umieścić go w męskim monasterze, gdzie mógłby się schronić przed Żydami. Przy okazji skłamał w sprawie swego wieku stwierdzając, że ma siedemnaście lat, gdy faktycznie miał niespełna piętnaście i pół. Podanie w języku rosyjskim podpisał jako Lazar Zamenhof ${ }^{17}$. Sporządzona przy tej okazji opinia dyrektora szkoły o Ludwiku kończy się stwierdzeniem: „Da Bóg, że w świętym chrzcie Duch Boży zamieszka i nakieruje Zamenhofa na droge pracy i prawdy, ale do obecnego czasu reprezentował on sobą nie budzące zaufania próżniactwo" 18.

Zgodnie $\mathrm{z}$ rosyjskim prawem, Zamenhof mając prawie 16 lat mógł samodzielnie decydować o swym wyznaniu, ale po uzyskaniu zgody odpowiedniego urzędu. Rodzice z całej procedury byli wyłączeni. Skoro więc Ludwik ostatecznie pozostał wyznawcą mojżeszowym, to albo mu odmówiono, co po takiej opinii byłoby zrozumiałe, albo do „rozumu” przemówił mu ojciec i zabrał go z Grodna do Białegostoku lub Warszawy, gdzie w końcu ukończył gimnazjum. Reakcja rodziny na wieść o porzuceniu szkoły, a szczególnie o chęci zmiany wyznania musiała być szokująca. Żydzi przechrztę traktowali jak zmarłego. Odnalezione podanie z 1875 r. jest najstarszym dochowanym do naszych czasów oryginalnym dokumentem napisanym przez Ludwika.

Nie wiadomo jak potoczyłyby się dalsze losy Zamenhofa, gdyby zamiary wynikające $\mathrm{z}$ młodzieńczych problemów carski urzędnik wprawił w czyn. Kto wie, czy Ludwik pochłonięty niezwykle rozbudowaną carską biurokracją miałby wówczas czas na dzieło swego życia - ESPERANTO ${ }^{19}$. Przytoczone nieznane fakty $z$ życia Zamenhofa w żadnym stopniu nie stanowią ujmy dla jego ponadczasowych dokonań.

17 Ibidem, k. 1-1v.

18 Ibidem, k. 4.

19 Język esperanto był wykorzystywany i do celów politycznych. Działacze komunistyczni w latach 50. i 60. XX w. dostrzegali w nim przeciwwagę dla języka angielskiego uznawanego $w$,świecie zachodnim” za międzynarodowy. W Polsce nawet radio nadawało audycje w języku esperanto. 
Po latach Ludwik doszedł do jeszcze innego wniosku. Uznał, że uniwersalny język to za mało, aby zbliżyć Żydów do innych narodów i zaproponował nową uniwersalną religię. W $1901 \mathrm{r}$. wydał po rosyjsku broszurę opartą na myślach starożytnego filozofa Hillela, w której postawił tezę o potrzebie zreformowania i przeobrażenia judaizmu w czysty monoteizm, nie uznający innego prawa $z$ wy jątkiem prawa miłości bliźniego. Idea ta zwana homaranizmem, okrzyczana przez ortodoksyjnych Żydów jako sekciarska, nie znalazła zwolenników i została zapomniana ${ }^{20}$.

Przybliżone fakty dowodzą, że dotychczas mieliśmy do czynienia $z$ ogólną i błędną w szczegółach biografią Ludwika Zamenhofa. Za kilka lat (2009) będziemy obchodzili 150. rocznicę urodzin twórcy Esperanto, wcześniej (2007) 90. rocznicę śmierci. Są one dobrą okazją do podjęcia kolejnego wysiłku mającego na celu napisanie nowej biografii, opartej na lepszej podstawie źródłowej. Nie tylko białostocki rozdział z życia Zamenhofa można uzupełnić. Przykładowo w Grodnie zachowała się szczegółowa ankieta jego rodziny ze spisu 1897 r. Myślę, że dzięki odnalezionym dokumentom postać „Białostoczanina XX w." stanie się jeszcze ciekawsza.

20 EE, t. VII, kol. 666; t. XII, kol. 632; Homo sum [pseudonim L. Zamenhofa], O Gillelizme, Petersburg 1901; L. Zamenhof, Pri la Homaranismo, „Ruslanda esperantisto” 1906, nr 5, s. 102-106; J. M. Parzyszek, Homaranizm Zamenhofa, „Gryfita” 1999, nr 19, s. $28-30$. 